\title{
Caetés: \\ nossa gente é sem herói ${ }^{1}$
}

\author{
Erwin Torralbo Gimenez ${ }^{2}$
}

\section{Resumo}

Centrado na análise de Caetés, primeiro romance de Graciliano Ramos, o ensaio procura examinar o processo de formulação das idéias e dos aspectos formais, ainda sob impasses, que já indicia o projeto do autor: a impossibilidade de tornar o índio uma figura épica, desmistificando o passado e provando os seus reflexos contínuos no ciclo de explorações; o adensamento do núcleo conservador dessa lógica, construída na metonímia de uma pequena cidade, onde se preservam as marcas de uma história sem rupturas efetivas; e, em especial, o percurso do narrador rumo à consciência que, apesar de só se insinuar ao fim, encerra o livro com o desalento de quem já não escapa ao reverso das ilusões. Trata-se, com efeito, de um esboço de romance moderno, ajustado à matéria brasileira, pois promove a revisão dos descompassos nacionais, trazidos à tona na medida em que conduz o protagonista à reflexão solitária, para fora dos vícios ordinários do ambiente.

\section{Palavras-chave}

Graciliano Ramos; romance brasileiro; pobre-diabo; narrador erradio

1 Este texto apareceu, originalmente, como um capítulo de minha tese de doutoramento, que versou sobre os romances em primeira pessoa de Graciliano Ramos. GIMENEZ, Erwin Torralbo. Graciliano Ramos: o mundo coberto de penas. 2005. Tese (Doutorado em Literatura Brasileira) - Faculdade de Filosofia, Letras e Ciências Humanas, Universidade de São Paulo, São Paulo, 2005.

2 Professor de Literatura Brasileira da Faculdade de Filosofia, Letras e Ciências Humanas da Universidade de São Paulo.

E-mail: torralbogimenez@bol.com.br 


\title{
Caetés: \\ no hero for our people
}

\author{
Erwin Torralbo Gimenez
}

\section{Abstract}

Centered in the analysis of Caetés, Graciliano Ramos's first novel, the essay tries to examine the formulation process of the ideas and the formal aspects, still under some impasse, that already indicates the author's project: the impossibility to make the Indian into an epic figure, demystifying the past and proving its continuous reflexes in the cycle of explorations; the thickening of the conservative core of that logic, built up on the metonym of a small town where the marks of a story without effective breaks are preserved; and, specially, the narrator steps towards the conscience which, despite the insinuation presented only in the end, finishes his book with the feeling of not escaping from the illusions reversal. It is, in fact, a sketch of the modern novel, adjusted to the Brazilian subject, for it promotes the reconsideration of the national differences, brought to the surface at the same time it leads the protagonist to the lonely reflection outside the ordinary vices of its environment.

\section{Keywords}

Graciliano Ramos; Brazilian novel; poor devil; erratic narrator. 


$$
O
$$


De resto, nenhum pensamento, nenhuma ação, muito falar. Temos a idolatria da palavra, vazia embora. É comparando mal, coisa semelhante ao culto do selvagem que adora a feição material de seus grosseiros manipanços de pau. A idéia escapa-lhes. Nossa preocupação máxima é falar bonito.

O país é preguiçoso. Dormir é a grande felicidade da vida. Coerentemente, a cidade dorme ou sonha acordada. Acordada? Engano. Vive numa modorra. De longe em longe estira os braços, espreguiça-se num bocejo, esfrega os olhos - e volta a mergulhar a cabeça nos travesseiros.

[Graciliano Ramos, 1921]

\section{A crônica em xeque}

A técnica pessoal em arte, quando se lida com um criador capaz de engendrá-la, costuma mostrar-se, em seus traços ainda não de todo consumados, já nas primeiras obras. É nos rastros iniciais da sua produção, talvez, e menos nos títulos bem acabados, que devemos começar a investigar a idéia e a expressão particulares, o sentimento e a perspectiva, o estilo enfim, responsáveis pela arquitetura própria de um escritor, no caso da literatura, a grafar a sua verdade. Escapando à solidão necessária para construir a sua visão, o autor converte, na forma literária, o conceito pessoal em testemunho coletivo. Porém, ele não se faz sozinho, embora aspire à originalidade, porque partilha do cotidiano comum e da tradição artística - o seu trabalho se obstina em penetrar a cultura, em termos de juízo e de estética.

Quem se dedica a divisar o engenho de Graciliano Ramos, portanto, precisa atentar para o seu livro de estréia: Caetés. Publicada em 1933, apesar de composta entre os anos de 1925 e 1928, a obra traz a marca dos pontos isolados, cujo lugar é difícil determinar meio às tendências da época, e trai os germes de um projeto literário ímpar. Após escrever poemas e crônicas sob pseudônimo, o autor resolve ceder à instância de um editor carioca, assinando um romance que escondia na gaveta. É verdade que não se alça, ainda, ao nível dos títulos posteriores, mas, por isso mesmo, deixa entrever, no descosido da forma, as linhas de força da técnica que depois se potenciaria já sem impasses. Bem, se seria injusto erguer o livro ao patamar dos romances seguintes, mais injusto seria descartá-lo porque está à sombra dos demais. 
Numa anamnese sobre o próprio ofício, Graciliano declara:

[...] É certo que, por volta dos treze anos, achei que devia ser agradável construir uma espécie de Inocência ou Casa de Pensão e fiz algumas tentativas. Com o correr do tempo os modelos se tornaram maiores, mas aí veio o bom senso e vieram ocupações razoáveis: a idéia de ser literato desapareceu completamente.

Rememora também que, anos mais tarde, vendo-se em situação adversa, apela à literatura para expurgar certas admoestações e rabisca uns contos; quanto a Caetés, recorda constrangido:

[...] O terceiro conto estirou-se demais e desandou em romance, pouco mais ou menos romance, com uma quantidade apreciável de tipos miúdos, desses que fervilham em todas as cidades pequenas do interior. Várias pessoas se julgaram retratadas nele e supuseram que eu havia feito crônica, o que muito me aborreceu. ${ }^{3}$

À parte o desencanto dessa autocrítica - aliás Graciliano foi talvez o leitor mais severo de si mesmo -, convém retirar dela dois comentários para a nossa reflexão: primeiro, as leituras juvenis, que se nutriam de românticos e naturalistas, causaram-lhe grande estímulo a princípio, porém o senso maduro aos poucos o impelia a idear "modelos maiores", os quais intentariam provavelmente vencer os limites das referidas escolas, de maneira a representar melhor as tensões - isto é, impõe-se ao literato em esboço a necessidade de superar a tradição, movê-la por meio de um empenho aproximativo aos contornos do momento. Segundo, o seu romance de estréia, embora pareça haver nascido quase por acidente, decerto se destinava a cumprir aquela expectativa antes ideada; conforme o público não lhe confere tal valor, julgando-o trabalho raso de cronista, o autor se ressente do livro e prefere abjurá-lo.

Todavia, se nos aprofundamos no exame do romance, sem as mesmas prevenções, vemos que Caetés, enquanto estrutura e exercício irônico, ensaia a conversão das narrativas precedentes. Em termos dos eventos, destecem-se, nos reveses da trama, as ilusões que faziam comover nos folhetins românticos: a impossibilidade de tornar o índio uma figura épica, desmistificando o passado e provando as suas projeções contínuas no ciclo de explorações e a efemeridade do enlace amoroso, cujo arrebatamento não transcende à inconstância humana. De outro lado, essa ironia sobre os idealismos não encerra, como acontecia no naturalismo nacional, uma

3 RAMOS, Graciliano. Alguns tipos sem importância. In: Linhas tortas. São Paulo: Martins, 1970. 
simples denúncia dos avessos: o adensamento do centro conservador de uma lógica perversa, construída na metonímia de uma pequena cidade, onde se preservam as marcas de uma história sem rupturas efetivas, não redunda em desprezo pela nossa realidade, mas se detém em atravessá-la para saber reagir aos seus embustes.

O desenho novo que então se percebe na composição do romance, e por isso Caetés indicia a técnica do autor, se firma em buscar um ponto de equilíbrio entre os elementos constitutivos da narrativa: se a subjetividade não se pode derramar ingênua, sofrendo uma educação em face dos reversos, tampouco os valores objetivos conseguem suplantá-la. Tal sondagem apenas se insinua porque se quer escorregar das noções estritas; em vez de paralisar a personagem, para além ou para aquém das contingências, ela a acompanha em seus choques com o contexto. Trata-se, com efeito, de um esboço de romance moderno, ajustado à matéria brasileira, pois promove a revisão dos descompassos nacionais, trazidos à tona na medida em que conduz o protagonista à reflexão solitária, para fora dos vícios ordinários do ambiente.

À primeira vista, Caetés sugere um mero registro de cotidiano tacanho e dos tipos miúdos que se condicionam à sensaboria da província. Relatando a vidinha de uma cidade do interior, Palmeira dos Índios, com seus costumes e sua pasmaceira, onde domina a velha prática do mandonismo e se multiplicam figuras características, aparentemente se prende à análise curta das crônicas sociais ${ }^{4}$. Seria tão só isso, se não se forjasse certo expediente: a descrição do espaço sempre nos chega filtrada pelo crivo de um narrador que, imerso nesse mundo, oscila entre a adesão embotada ao meio e vagas inquietudes a respeito da sua lógica. De forma incipiente, mas crescendo no passo do seu percurso, o narrador-protagonista rasga no texto uma fenda através da qual se vão tornando dramáticas as experiências - diferente, logo, do juízo afastado e anti-lírico do determinismo,

4 A crítica, o mais das vezes, relega Caetés ao plano do documento, considerando-o um romance falhado. Carlos Nelson Coutinho, por exemplo, conforme se esforça por introduzir as teorias luckasianas na interpretação da obra de Graciliano Ramos, conclui que o livro não vai além da descrição estéril do ambiente pequeno, deixando, assim, de atingir o caráter problemático que só a narração, técnica que segundo o crítico o escritor incorpora nos demais romances, pode iluminar: "[...] O universo deste romance não ultrapassa a representação da superfície da realidade; trata-se de uma crônica, do relato quase jornalístico de uma cidade do interior nordestino. Um tênue enredo, disposto em torno de um fait divers, não consegue organizar e unificar o universo do romance, criando-lhe uma estrutura que seja análoga à estrutura global do real. Naturalmente, parcelas da realidade, isoladas do conjunto, estão reproduzidas em Caetés; não porém o movimento da totalidade do real, único conteúdo que pode permitir ao escritor a construção de uma forma épica verdadeiramente artística." (GRACILIANO Ramos. In: BRAYNER, Sônia (Org.). Graciliano Ramos: coleção fortuna crítica. Rio de Janeiro: Civilização Brasileira, 1978.) 
aqui as vicissitudes tumultuam a idéia do indivíduo, arrastando-o em graus cada vez mais tensos até contrair o desalento de quem já não se esquiva ao impacto das derrotas.

Contrariamente ao que pregam os detratores de Caetés, a sua estrutura não se difunde entre variados quadros, carecendo de unidade de sentido; esse parecer corresponde à crônica, mas se levamos em conta que o livro visa exato ao deslizamento da superfície social para a meditação íntima, em avanço gradativo, aí se revela a coesão de estrutura. A análise do primeiro capítulo já aponta o norte de construção que, desdobrando-se, garante ao conjunto um alcance mais amplo.

Principiando o romance em media res, a cena de abertura nos lança na sala de Adrião, durante uma das reuniões periódicas, às quais freqüenta um grupo seleto de convivas; a um canto, João Valério, o narrador, se atreve abrupto a beijar a esposa do anfitrião, Luísa; mediante o espanto da mulher, Valério se retira agoniado com o que fizera. Enquanto caminha só, vai pela rua avaliando os apuros que lhe causaria aquele arroubo, e então sabemos que trabalha como guarda-livros na firma do velho negociante, tomando parte também nos chás em sua casa, e que já havia algum tempo estava apaixonado por sua jovem esposa. Passa a descrever o ritmo insosso das reuniões, quando, alheio ao burburinho em sua volta, entregava-se aos devaneios e adorava a imagem de Luísa. Perceba-se que essa inclinação de Valério para o alheamento, incapaz de fixar-se nas rodas coletivas e nelas apagar-se junto aos demais, corresponde à cena presente: tanto como divagava sem participar dos jogos e das conversas, ora anda solitário após sair do âmbito social, relembrando o que lá havia ocorrido. Há, espacialmente, um manejo de espelhos: do convívio geral para o fluxo particular, da sala cheia para a rua deserta e, ao fim do capítulo, da cidade para o quarto de pensão, onde conjectura sobre o seu destino.

Com efeito, esta será a estratégia de composição do romance: os episódios da esfera pública não servem senão como motivos que, carreados para as reflexões de Valério, vão, lenta e obliquamente, moldando-lhe a consciência; o arremesso às fantasias do seu espírito o arranca da prática comum, mas o revés que a cada uma delas se impõe, quando em face da realidade, o faz sentir o contrapeso das ilusões ${ }^{5}$. E mais: conforme se acirra

5 Antonio Candido, para relativizar a tão alardeada influência de Eça de Queiroz sobre Caetés, pondera: “[...] À técnica, praticada segundo molde queirosiano, junta-se algo próprio a Graciliano: a preocupação ininterrupta com o caso individual, com o ângulo do indivíduo singular, que é - e será - o seu modo de encarar a realidade. No âmago do acontecimento está sempre o coração do personagem central, dominante, impondo na visão das coisas a sua posição específica." (CANDIDO, Antonio. Ficção e confissão. São Paulo: Editora 34, 1999.) 
o processo na zona do indivíduo, a visão ascende do seu fracasso para o fracasso do mundo que o aniquilou - ao fim, a metonímia da cidade pequena se abre em chave maior, desenredando a fisionomia do país.

Ao sentenciar que Caetés se conserva nas raias horizontais da crônica, sendo a sua estrutura um punhado de retratos sem elos entre si, a crítica ignora justo o empenho do escritor. A unidade orgânica deste romance, disposta com vistas a fraturar o espraiamento descritivo, se realiza a partir de uma força centrípeta - o sujeito da escrita - que traga os fatos exteriores e sobre eles imprime uma dúvida precária, porém evolutiva. Toda obra cujo propósito é desmontar uma forma literária congrega ao mesmo tempo os elementos de tal forma e o seu contraponto transformador; é assim, pois, que Caetés arranja e desarranja os traços substantivos da crônica: espalha os quadros na superfície e em seguida os faz refluir para a verticalidade pessoal. Não se trata, contudo, de uma cisão, como a dividir o livro em dois momentos, porque esse andamento se repete a cada passagem, a fim de representar a formação do narrador. Deve-se assinalar que tal experimento, embora se mostre coerente em seu esquema, não deixa de esbarrar em limites: ao tornar o protagonista um abismo dentro do entrecho, com sua percepção vacilante, elabora mal as múltiplas figuras em redor dele. Se o narrador atinge ao cabo do seu percurso um estado problemático, as demais personagens parecem permanecer na mediania.

\section{O pobre-diabo em esboço}

A escolha de João Valério como ângulo de apreensão desse contexto medíocre, a propiciar um ponto de fuga dentro do universo imóvel, não é casual. Decadente da velha aristocracia rural, e enganado quanto à partilha de uns poucos bens, Valério foi instalar-se em Palmeira dos Índios onde exercia um humilde cargo na casa Teixeira \& Irmão. O caráter indeciso da sua situação - entre o orgulho de mandante decaído e a cobiça de voltar ao mando - percute em sua instabilidade psíquica, a qual pendula entre o anseio de vencer naquele mundo, absorvendo as suas artimanhas, e certa reserva nem sempre abafada contra aquele mundo. No meio de um tecido social sem mudanças, o autor encontra um foco ainda não cristalizado, permeável portanto ao desassossego que interroga os fatos ordinários; ora seduzido pela norma ora avesso a ela, o guarda-livros simboliza uma fissura favorável à análise da lógica geral. Insatisfeito, pois não consegue acomodar-se aos "aborrecimentos que fervilham nesta vida pacata, vagarosamente arrastada", Valério deriva para o excurso do desejo; interditos, no ambiente estreito, os seus desejos, ele compreende pouco a pouco o circuito 
cerrado de que é vítima. Estudando um ângulo assim oscilante, o autor traceja os passos da formação de uma personagem vulnerável às ilusões e cativa do fracasso.

Das várias vezes em que o narrador depara com a própria inconstância, agastado e preguiçoso, uma sugere sem equívoco a sua posição de desnaturado no meio, e também o quase lamento de nele não saber conformar-se. No capítulo 16, Padre Atanásio, cujas opiniões fortes sempre servem de contraste à lógica dos enganos, transmite a Valério a oferta de emprego na firma de Mendonça, com as vantagens de melhor salário e interesse nos lucros; de início, o guarda-livros tende a aceitar, pois seria um modo de fugir a Luísa, que então o trazia muito atordoado, mas termina recusando. A recusa contenta ao padre, que a reputa à fidelidade de Valério aos patrões (“- Perfeitamente, concordou o vigário. Recusa, mas não tem senso comum.”), sem suspeitar que o móvel era no fundo estar próximo à esposa de Adrião. Porém, a resposta do narrador é o que bem dimensiona o seu desconcerto, já em parte pressentido: “- Não tenho nada, nem senso nem coisa nenhuma. Sou um desgraçado.” - isto é: a essa altura dos acontecimentos, pela metade do livro, Valério se dá conta de não participar da ordem geral, porque cada vez mais se permite guiar pela emoção e menos pelo cálculo, mas em contrapartida percebe que as suas veleidades, se o afastam do comum, também não chegam a lhe definir nenhuma outra feição, e a sua desgraça parece ser ziguezaguear sem jamais invadir o sentido das coisas.

O capítulo seguinte repete, de fato, a estrutura antes mencionada: toda a cidade desfila na procissão natalina, percorrendo os bairros até o ponto mais alto, onde se localiza a igreja; Valério observa, à margem, e quando o chamam a tomar parte no cortejo, prefere adiantar-se e esperar lá em cima. Apartado da festa coletiva, sobrevém outra vez o pendor para a auto-análise, que aliás lhe vem sempre à revelia de sua vontade; a seqüência de impulsos e recuos do seu desejo enfim leva o sujeito a suspeitar os giros do engano em que está enovelado. O enquadramento espacial da cena reflete essa espécie de saliência que Valério acaba por representar, de forma acanhada, na planura do ambiente mesquinho: do alto e solitário, enxerga o que ninguém pode ver lá de baixo - será assim a paisagem que lhe revelará, pela correspondência, o seu emparedamento, mas com isso lhe estorvará a invenção de novas quimeras. É o primeiro instante agudo a lhe ferir os devaneios:

Encostei-me à grade de ferro que circunda a calçada.

Montes à esquerda, próximos, verdes; montes à direita, longe, azuis; montes ao fundo, muito longe, brancos, quase invisíveis, para as bandas do S. Francisco. Acendi um cigarro. E imaginei com desalento 
que havia em mim alguma coisa daquela paisagem: uma extensa planície que montanhas circulam. Voam-me desejos por toda a parte, e caem, voam outros, tornam a cair, sem força para transpor não sei que barreiras. Ânsias que me devoram facilmente se exaurem em caminhadas curtas por esta campina rasa que é a minha vida. ${ }^{6}$

É preciso perguntar: quais são os desejos que, em sua travessia, se aventuram para logo despencar? Três saltos, três quedas: narrar os feitos heróicos dos índios caetés, amar a uma mulher enlevadamente, subir na carreira do comércio. Se é verdade que tais fantasias advêm de um ânimo insatisfeito e se alimentam de certas falácias do imaginário brasileiro, então esgarçá-las uma a uma significa investigar agudamente a nossa realidade. Os delírios do guarda-livros são investidas contra a obscuridade e a monotonia, planos de evadir-se de um entorno que em tudo lhe resulta mofino; contudo, as suas ilusões se valem dos referentes do próprio espaço, porque o cegam e fascinam as imagens criadas pelo discurso da ordem. Eis a ironia do romance: apontar a medula lograda desse mundo a partir da trajetória de um jovem que pensa ter vez de vencer aquilo que o tem vencido.

Ironicamente, João Valério esconde o dinheiro para as suas despesas ordinárias na Bíblia, justo no Eclesiastes, onde se pode ler na primeira página: "O que foi, será, o que se fez, se tornará a fazer: nada há de novo debaixo do sol!".

\section{Três vôos, três quedas}

Nem bem chega a Palmeira dos Índios, o órfão decadente já planeia um modo de suprir o seu desamparo com escrever um livro, visto que não possuía recursos e só lhe restava o talento para sair da sombra. Decide-se a compor um romance histórico, enaltecendo a bravura dos indígenas que, no passado, deram prova de valentia ao aprisionar os portugueses que ali aportaram após um naufrágio e devorar o Bispo Sardinha. Embora o fato não passasse de um momento de exceção na historiografia, cuja regra se fez de massacres sobre os índios, repontava como lenda épica a enobrecer os filhos da terra. Sem se ocupar de estudos ou de tentar um juízo crítico acerca da matéria, interessa a Valério somente atrair a admiração dos seus pares, e assim o gênero elevado de uma epopéia se afina como nenhum outro ao seu intento. Afinal, os folhetins venturosos ainda suscitavam enorme encanto entre os provincianos e remediavam a angústia da pátria sem identidade. Da parte de Valério, no entanto, não há qualquer indústria 
enganosa, quer dizer, ele apenas deseja imitar os modelos que lhe haviam infundido tanta exaltação na escola, e não manejar essas fantasias a fim de velar o triste legado, sendo ele próprio mais um dos que se fiavam na memória oficial e literária. Ocorre que, lidando com a tarefa, quando as incongruências aparecem - e aí se reproduz a constante do senso geral ao particular, ora num declínio da versão comum à interrogação pessoal -, Valério se frustra com o substrato histórico, incapaz de extrair dele um valor altivo:

Também aventurar-me a fabricar um romance histórico sem conhecer história! Os meus caetés não têm verossimilhança, porque deles apenas sei que existiram, andaram nus e comiam gente. Li, na escola primária, uns carapetões interessantes no Gonçalves Dias e no Alencar, mas já esqueci quase tudo. Sorria-me, entretanto, a esperança de poder transformar esse material arcaico numa brochura de cem a duzentas páginas, cheia de lorotas em bom estilo, editada no Ramalho. [...]

Caciques. Que entendia eu de caciques? Melhor seria compor uma novela em que arrumasse padre Atanásio, o dr. Liberato, Nicolau Varejão, o Pinheiro, d. Engrácia. Mas como achar enredo, dispor as personagens, dar-lhes vida? Decididamente não tinha habilidade para a empresa: por mais que me esforçasse, só conseguiria garatujar uma narrativa embaciada e amorfa. ${ }^{7}$

É durante a empreitada que Valério, leitor ingênuo dos românticos, se dá conta de não saber nada a respeito de um passado tão caro à sua imaginação. Enquanto se entretinha passivo com as idéias falsas, transfiguradas num tempo remoto, jamais suspeitou serem fruto de um artifício; quando se abalança a exercer o papel ativo da composição, tendo de trabalhar sobre o material, manifesta-se a sua ignorância e a escrita emperra. De início, essa inabilidade apenas revela, empiricamente, a ausência de espírito crítico no sujeito médio da nossa realidade, enevoado pelos lances heróicos de uma memória construída ${ }^{8}$. Para o guarda-livros, há uma dissensão evidente entre ele, civilizado, e os indígenas, selvagens - conquanto os feitos destes tinjam de glória o nosso passado, já se rompeu de todo o laço e o presente está

7 Ibidem. cap. 3.

8 Exemplo dos mais emblemáticos (para não dizer risíveis) é o texto de Affonso Celso, Por que me ufano de meu país, cujo êxito editorial desde 1900 dá mostra da tendência mitificadora do ideário nacional quanto ao seu passado: "Na sua história, relacionada com os mais notáveis acontecimentos da espécie humana, escasseiam guerras civis e efusões de sangue, sobejando feitos heróicos, formosas legendas, preclaras figuras, luminosos exemplos." (CELSO, Affonso. Por que me ufano de meu país. São Paulo: Expressão e Cultura, 2001.) Graciliano Ramos manifestou, com dura ironia, a sua aversão a esse tipo de discurso inflado e equívoco, ao avaliar o autor: "O sr. conde Afonso Celso, varão 
voltado para os rumos modernos, europeizados. Daí não se fazer necessário inquirir se verídicos ou não os fatos, nobres e superados. Mas, instigado a representar o presente, o narrador também se mostra inepto; convencido do divórcio entre o Brasil antigo e o Brasil moderno, não consegue testemunhar sobre nenhum dos dois - evocando aquele e vivenciando este, irá no exercício da escrita duvidar das certezas antes impostas.

Ao insistir em terminar a epopéia, Valério sofre o maior desapontamento quando delineia justo a passagem central: o naufrágio da esquadra lusa e o rito antropofágico dos caetés. Ignora os expedientes de invenção, e a carência de adornos, espécie de realismo involuntário, o conduz a ver as coisas mais ou menos como deviam ter-se passado:

De mais a mais a dificuldade era grande, as idéias minguadas recalcitravam, agora que eu ia tentar descrever a impressão produzida no rude espírito da minha gente pelo galeão de d. Pêro Sardinha. Em todo caso apinhei os índios em alvoroço no centro da ocara, aterrorizados, gritando por Tupã, e afoguei um bando de marujos portugueses. Mas não os achei bem afogados, nem achei a bulha de caetés suficientemente desenvolvida.

Com a pena irresoluta, muito tempo contemplei destroços flutuantes. Eu tinha confiado naquele naufrágio, idealizado um grande naufrágio cheio de adjetivos enérgicos, e por fim me aparecia um pequenino naufrágio inexpressivo, um naufrágio reles. E curto: dezoito linhas de letra espichada, com emendas. Pôr no meu livro um navio que se afunda! Tolice. Onde vi eu um galeão? E quem me disse que era galeão? Talvez fosse uma caravela. Ou um bergantim. Melhor teria feito se houvesse arrumado os caetés no interior do país e deixado a embarcação escangalhar-se como Deus quisesse. ${ }^{9}$

Impossível narrar feitos nunca vistos, se não se propõe o escritor gerar fantasmas. Valério bem gostaria de saber gerá-los, pois ambiciona concluir o romance para ganhar prestígio na cidade; acontece que lhe falta a astúcia de novelista, ou melhor, não supunha haver tanta astúcia nas novelas lidas. Sem adquirir a ciência nos estudos, e inebriado com a retórica fantasista, é na experiência da escrita que ele tropeça nas dúvidas - e estanca diante delas. E a dúvida se gradua em sentimento do contrário; no capítulo 18, subseqüente à metáfora da planície e dos montes, o narrador

ilustre de outras idades, parecia muito firme e era precioso. Foi ele que nos habituou a temer esse patriotismo farfalhudo que olha para cima, cruza os braços e vive no mundo da lua; foi ele que, em matéria de composição literária, sempre nos deu lições valiosas mostrando, perseverante e desinteressado, como não se deve escrever." (RAMOS, Graciliano. Uma eleição. In: Linhas tortas. Op. cit.).

RAMOS, Graciliano. Caetés. Op. cit. cap. 7. 
diz haver abandonado os índios, e explica: "Para que mexer nos caetés, uma horda de brutos que outros brutos varreram?"

Um parágrafo abaixo, o segundo vôo infeliz repete a curva de descenso, indo da euforia à indiferença:

Só Luísa me preocupava. Desejei-a dois meses com uma intensidade que hoje me espanta. Um desejo violento, livre de todos os véus com que a princípio tentei encobri-lo. Amei-a com raiva e pressa, despi-me de escrúpulos que me importunavam, sonhei, como um doente, cenas lúbricas de arrepiar.

Como ficou dito, as primeiras páginas já anunciam o entorpecimento do narrador por causa da esposa de seu patrão; desvanece-o a candura de Luísa, em quem projeta a aura de um ser superior, digno de todos os seus cuidados: "A religiosidade de que a minha alma é capaz ali se concentrava”. À paixão se juntava ainda, acessória, a perspectiva de tomar ao chefe, depois de morto, além da mulher a herança. $\mathrm{O}$ espírito romântico de Valério se extravasa obcecado em torno a Luísa, que assim empresta aos seus desvarios apenas a imagem, cujo preenchimento se faz com as nuvens do amor ideal. Tornando-se amante de Luísa, às escondidas, sente aflorar em si a sensualidade, e o enlevo surge mudado em apelo erótico a saciedade aos poucos o força a duvidar, como no caso anterior, da infinitude de seus entusiasmos: "Mas todas as belas qualidades com que me entretive a enfeitar o meu ídolo seriam o que eu julgava?" Outra vez, a experiência faz Valério entestar com o avesso da ilusão, tombando frente às muralhas erguidas pela realidade ${ }^{10}$.

Com isto, pode-se inferir mais um elemento de desvio de Caetés em relação à narrativa tradicional: o triângulo amoroso, lugar-comum das tramas romanescas, aqui não aparece como a desgraça dos amantes espreitados pela convenção, impedidos de viver o amor elevado no mundo contra o qual se voltam - o que ora apaga a chama dos amantes é o fim do desejo. Após vencer a esquivança de Luísa, o guarda-livros passa a freqüentar a sua cama, quando o marido se ausenta da cidade; embora se

10 Graciliano Ramos, ainda na juventude, explicita o seu apego ao realismo, o qual considera a única seara competente ao escritor interessado em dar testemunho do seu tempo. Aos dezoito anos, concede uma entrevista à imprensa local, declarando: “[...] Prefiro a escola que, rompendo a trama falsa do idealismo, descreva a vida tal qual é, sem ilusões nem mentiras./ Antes a 'nudez forte da verdade', que o 'manto diáfano da fantasia'// Dizem por aí que os realistas só olham a parte má das coisas./ Mas, que querem?/ A parte boa da sociedade quase que não existe./ De resto, é bom a gente acostumar-se logo com as misérias da vida. É melhor do que o indivíduo, depois de mergulhado em pieguices românticas, deparar com a verdade nua e crua.” (Apud SANT’ANA, Moacir Medeiros de. Graciliano Ramos: achegas bibliográficas. Maceió: Arquivo Público de Alagoas, Senec, 1973.) 
acautelem, logo o caso transpira entre os palmeirenses, e Adrião recebe uma carta anônima que lhe denuncia o adultério; interpelado pelo patriarca traído, Valério nega tudo, mas Adrião teme o escândalo e mete uma bala no peito; agoniza até que enfim falece. Todos sabem ou desconfiam do real motivo do suicídio, porém a ordem trata rápido de abafar a verdade malvinda, e o médico arruma como pretexto não agüentar mais o pobre velho os achaques nervosos e preferir a morte. Absolvidos pelo silêncio cúmplice da cidade, Luísa e Valério poderiam casar-se, não fosse o arrefecimento desde antes fatal à paixão. De fato, o narrador usa menos de cálculo que de sentimento, porque, se tivesse aprendido a inserir-se na lógica dos interesses, assumiria o posto de Adrião na casa e na firma. Compungia-o, entretanto, ver gorar-se mais uma quimera, e quando vai procurar Luísa, dois meses depois, já o faz por mera obrigação moral ("Hipocrisia: todos os meus desejos tinham murchado.”). A frieza da última entrevista obstrui qualquer reconciliação (“- É que desapareceu tudo.”, sentencia Luísa), e Valério tem de mirar o próprio tamanho tal qual a nova queda o reduzira: "E tentei adornar Luísa com os atributos de que a tinha despojado./ - Para quê? refleti. É melhor assim./ Eu agora era um pequenino João Valério, guarda-livros mesquinho." (cap. 29)

A terceira falência do protagonista diz respeito ao fator econômico. Como aristocrata destituído de posses, Valério tem de empregar-se numa firma comercial, onde trata da escrituração; sem dominar a malícia dos negócios, exerce uma função burocrática, mas inveja os donos da nova ordem e almeja fazer-se um deles. Com efeito, detém somente um conhecimento formal, típico dos descendentes da velha classe, ignorante dos meandros próprios à atividade especulativa - já no começo, espanta-se com a sua inépcia para o mercado: “...admirei o tino de Adrião. Não serei um comerciante nunca." Ademais de não apreender a lógica burguesa, pois provém de outro sistema, a sua índole indisciplinada e flutuante lhe impede treinar o raciocínio, de modo a arraigar em si as argúcias de arrivista - a ascensão financeira era para ele mais um desvario que um projeto. Por isso, também inveja os bacharéis que, bem afinados com o curso das conveniências, amealham os lucros que ele cobiça sem saber como obter. Verdadeiro arrivista, na região, é Evaristo Barroca: figura característica da era burguesa, operou com sucesso os seus meios, usando do diploma para ganhar respeito e meter-se na prática dos favores e na política, afetando uma cultura de almanaque, trazendo às suas mãos os bens da aristocracia: "Aquele, sim, anda sem se deter e alcança tudo com facilidade. Vence os embaraços, corta-os, e o que vai encontrando serve-lhe de meio para avançar. Que bandido!" Apesar de presumir, de vez em vez, os sintomas dessa sociedade, nova apenas nas formas de ação, o guarda-livros é incapaz de 
manejar os seus cordões, o que fica claro quando se refere ao jogo de xadrez, explorado no romance como espelhamento da praxis social: “...não me entravam na cabeça aquelas combinações embrulhadas. Afinal sempre me resignava a perder uma partida."

O capítulo 30 encerra, ironicamente, o ciclo malogrado em que gira o pobre-diabo João Valério. Morto o cabeça da firma, Adrião, o guarda-livros é promovido a sócio, a convite de Vitorino, o Teixeira ocioso. Imaginando-se vencedor, pretende apagar em si os vestígios de evasão, compenetrar-se do pragmatismo de um negociante; os reveses acolhidos em seu espírito lhe parecem, ainda, não se implicarem em nada com o presente, ao qual se deveria prender. Entretanto, para nós leitores, reponta o sentido circular do seu percurso: o protagonista se encontra, ao fim, na mesma situação do início. Basta analisar o primeiro parágrafo para verificar que tudo roda sem sair do lugar: "Decorreram mais três meses. Passei a sócio da casa, que Vitorino não pode dirigi-la só; Luísa é hoje comanditária; a razão social não foi alterada." - note-se, na cadência do período, o movimento enganoso que tal entorno, inabalável, descreve: o tempo transcorre, Valério sobe um degrau na firma (mas já se sabe que em virtude de o patrão necessitar de auxílio), a viúva do outro sócio herdou parte dos fundos, e o sobrenome do novo sócio não consta na placa - isto é: sob a aparente mudança resiste a conservação. Qual a percentagem de Valério na sociedade, dado que o espólio de Adrião coube a Luísa e Vitorino, é óbvio, não renunciou ao seu quinhão? O prêmio do protagonista se limita a ter redobrado o serviço, em favor do irmão que restou, este, sim, beneficiado com o sumiço do chefe:

Todos os dias, das oito da manhã às cinco da tarde, trabalho no escritório, e trabalho com vigor. Temos ocupação: precisamos inspirar confiança à freguesia e sossegar os fornecedores, mostrar-lhes que podemos gerir o estabelecimento na falta do chefe que desapareceu.

Continuo na pensão de d. Maria José, mas aos domingos janto com Vitorino. Quase sempre vai Isidoro. A Teixeira, excelente dona de casa, traz aquilo muito bonito. Há no salão duas paisagens a óleo. Os móveis da sala de jantar foram substituídos por outros, onde porcelanas e cristais novos brilham. Uma habitação confortável. ${ }^{11}$

Enquanto a vida do narrador permanece em igual modéstia, apenas aumentado o trabalho com o título de sócio, a de Vitorino se areja de vantagens. A ironia do autor, oculto atrás da ilusão de Valério, consiste em

11 RAMOS, Graciliano. Caetés. Op. cit. 
colocá-lo exato na posição do começo, variando só o cenário: à semelhança do início, ele freqüenta a casa do patriarca, ora Vitorino, e transfere o desejo antes projetado em Luísa para Josefa, a filha do anfitrião, com quem sonha à noite, sozinho: "No silêncio do meu quarto, penso às vezes que a vida com ela seria doce. [...] Parece-me que vou casar com a Teixeira." o círculo se fecha, perfeito: a condição atual da personagem em nada contradiz aquela da primeira cena, pois o estado de coisas não lhe abriu qualquer brecha, e ele tampouco a soube abrir por si mesmo; em paralelo ao efeito inútil de os caetés haverem devorado o bispo português, já que os índios acabaram dizimados, o fato de Valério “devorar" Adrião, tomandolhe o posto, equivale também a uma falsa vitória.

Porém, o devaneio econômico, mal fincado na ordem presente, não se salva de decair e, esboroando-se, será a gota d'água a inundar a consciência do narrador. Em simetria exata com a estrutura do romance, sempre afunilando o foco para o olhar do protagonista e repuxando-o do senso comum, as últimas páginas vão lançá-lo naquele mesmo ponto elevado, onde antes sofreu a primeira fisgada lúcida: "Entrei a vagar pela cidade, maquinalmente, levado por uma onda de recordações. À boca da noite achava-me na calçada da igreja./ Da paisagem admirável apenas se divisavam massas confusas de serras cobertas de sombras.” Em caminhada solitária, e ora cumulado de fracassos, Valério se encontra outra vez acima do ambiente tacanho; a cidade dorme, abaixo, e os montes que o emparedavam já se nublam - não é que os tenha transposto com o êxito, mas, sim, com reconhecer, à custa das quedas, que eles o obrigam a enxergar-se pequeno. Quando se livra das ilusões, após experienciar os seus reveses, ganha a liberdade de saber-se preso. Tanto os enganos daquele mundo se infiltram em sua idéia que, por fim, a inquietação se traduz em consciência, ou melhor, o olhar inquieto já não cabe nos limites da cidade, à beira da consciência. Feito um eco às avessas, assim como ocorria durante a escrita da epopéia, a assertiva se relativiza em interrogativa: "Infelizmente não sou selvagem.” (cap. 3); "Que sou eu senão um selvagem, ligeiramente polido, com uma tênue camada de verniz por fora?" (cap. 31). Derrubado da imagem civilizada que lhe havia incutido a promessa moderna, a qual o asfixiava e diminuía, o guarda-livros se vê presa da mesma teia que antes deduzira prender os indígenas; derivando da sincronia à diacronia, sente percutir em seu itinerário um fado igual ao dos caetés, pois os irmana o fracasso ditado por uma lógica cerrada, cuja arte se dá em mudar os meios e conservar a essência: "Um caeté, sem dúvida." Ao topar com essa alteridade dramática, levanta os traços do caráter nacional ${ }^{12}$ - inconstância, preguiça,

12 José Paulo Paes, retomando as discussões em torno dos influxos de A Ilustre Casa de 
embrutecimento, imaginação desregrada, etc. -, cuja permanência na alma dos explorados (dos índios até ele) sempre os desviou de levar a cabo qualquer ruptura com a tradição brasileira, que assim risca círculos contínuos sem evoluir nem se formar: "Outras raças, outros costumes, quatrocentos anos. Mas no íntimo, um caeté." E as frases finais resumem bem o espírito vagabundo de um povo, incapaz portanto de mudar heroicamente a sua história: "Tenho passado a vida a criar deuses que morrem logo, ídolos que depois derrubo - uma estrela no céu, algumas mulheres na terra...”.

\section{O selvagem e o funcionário}

Aliado à revisão do pensamento nacional, em termos ideológicos e formais, está o problema peculiar do ângulo narrativo: distinto dos relatos em primeira pessoa, que se costumam fazer com o retrospecto do vivido, em Caetés o narrador se constrói quase colado aos eventos, de maneira a refletir o passo gradual de uma formação, movida pelas incertezas, numa espécie de educação sentimental à brasileira. À medida que os fatos lhe contrariam as expectativas, João Valério começa a converter a memória em testemunho, até que, digeridas as desventuras pelo crivo subjetivo, cessa de palpitar indeciso e chega a um julgamento. Para representar esse fenômeno, e deslizar da superfície social, o escritor forja um narrador erradio, cuja feição de vagabundo (vagueante, sem base firme) se presta a intuir as contradições do espaço. É assim que Graciliano se desvencilha do ponto de vista horizontal e examina criticamente as tensões, esboçando uma técnica pessoal ${ }^{13}$.

Antonio Candido, quando do cinqüentenário de Caetés, observa:

Ramires, de Eça de Queiroz, sobre Caetés, conclui que as obras se encerram em tons absolutamente opostos: enquanto aquela exorta os portugueses a reatar com o seu passado glorioso, pois a índole lusa lhe parece altiva, esta desvenda o sentido negativo do nosso caráter, de comum servil e inerte: "por serem o contrário das 'necessidades sociais' da civilização, elas não são virtudes, são vícios”. E então o crítico aponta em Caetés o constitutivo desiludido das figuras do autor, vendo em João Valério a primeira feição de pobre-diabo: "Termina assim Caetés num clima de descrença e malogro pessoal que se irá prolongar até São Bernardo, Angústia e Vidas Secas, os dois primeiros escritos também em primeira pessoa." (PAES, José Paulo. Do fidalgo ao guarda-livros. In: Transleituras. São Paulo: Ática, 1995.)

13 Segundo Walter Benjamin, o que caracteriza a prosa moderna é o ilhamento do sujeito em suas próprias experiências, retirado do convívio geral para reflexionar acerca do mundo: “[...] A matriz do romance é o indivíduo em sua solidão, o homem que não pode mais falar exemplarmente sobre suas preocupações, a quem ninguém pode dar conselhos, e que não sabe dar conselhos a ninguém. Escrever um romance significa descrever a existência humana, levando o incomensurável ao paroxismo." (BENJAMIN, Walter. A crise do romance. In: Obras Escolhidas I: magia e técnica, arte e política - ensaios sobre literatura e história da cultura. São Paulo: Brasiliense, 1985.) 
[...] as ambigüidades do texto, vinculadas à ironia criadora de Graciliano Ramos, ironia que está na estrutura e é um dos maiores encantos do livro. Com efeito, o narrador lamenta a própria incapacidade de escrever o romance sobre os índios e parece construir um vazio, que é a ausência do discurso planejado; mas simultaneamente, como sem querer, vai escrevendo algo mais importante: a história da sua experiência amorosa no quadro da pequena cidade. $\mathrm{O}$ seu fracasso é, portanto, o seu triunfo; o vácuo aparente é uma plenitude... ${ }^{14}$

E, se cabe fazer um trocadilho, o seu triunfo é conhecer o próprio fracasso, porque isto o emancipa da cegueira comum e lhe dá vez de penetrar o valor negativo da sua empresa no mundo, bem como pensar a negatividade do mundo. O título do romance - Caetés -, a lembrar os nomes de epopéia, como Os Lusíadas, reforça a ironia: impossível entre nós um canto épico, dado o círculo histórico, a nossa tragédia pode ser contada a partir de qualquer momento, pois passado e presente se comunicam.

Deve-se, contudo, ressalvar o preço pago ao ensaio de um "modelo maior": conforme a perspectiva se concentra inteira numa figura, traduzindo em sua particularidade os abalos gerais, faz convergir para esse abismo toda a carga problemática e obscurece, ou deixa por desenvolver, as demais personagens do enredo. Obstinado em autenticar um foco isolado, o autor hipertrofia o seu papel dentro do livro e com efeito o torna típico, mas esquece os que estão orbitando em redor dele no degrau dos médios ${ }^{15}$. Trata-se de um limite necessário ao projeto, pois só se pode pôr em xeque uma forma artística quando se posiciona o seu avesso dentro dela mesma. Tanto assim que certas personagens de feitio naturalista, ou seja, aquelas regidas pela face exterior, aparecem algo relativizadas sob o

14 CANDIDO, Antonio. No aparecimento de Caetés. In: Ficção e confissão. São Paulo: Editora 34, 1999.

15 Tais categorias foram longamente estudadas por Georg Lukács: "Apresenta-se aqui a escolha: o modelo para a caracterização artística deve ser a estrutura normal do típico ou a do médio? O princípio desta escolha implica, em resumo, o seguinte: se a forma da caracterização parte da explicitação ao máximo grau das determinações contraditórias (como no típico), ou se estas contradições se debilitam entre si, neutralizandose reciprocamente (como no médio). [...] No primeiro caso, vemos como a verdade da forma, que desenvolve o seu conteúdo médio de acordo com as proporções da vida real, engendra movimento e vitalidade no que é em si rígido; no segundo caso, vemos que o modo da realização formal na representação é muito mais pobre do que a realidade empírica imediata.” (LUKÁCS, Georg .O típico: problemas da forma. In:

Introdução a uma estética marxista. Rio de Janeiro: Civilização Brasileira, 1978.) Neste sentido, poderíamos dizer que, em Caetés, João Valério atinge a estatura do típico, pois as suas contradições se tensionam a ponto de a personagem escapar à mediania, enquanto as demais se mantêm quase inalteradas. 
prisma do narrador: o cientificismo biológico e político, cujos estigmas estão respectivamente em dr. Liberato e Miranda Nazaré, embora causem admiração em Valério, logo redundam em disparate; o determinismo sexual, como em d. Maria José e Isidoro Pinheiro, perde o seu teor patológico e se verte em demanda afetiva: "Punham a sua felicidade onde podiam alcançá-la.” Um tipo menos rasteiro é Nicolau Varejão: sendo em tudo um pobre-diabo, sem nenhum mérito entre os seus pares, intenta ludicamente imaginar, com um espiritismo arrevesado, grandes passagens em suas vidas pretéritas, como se isso lhe corrigisse a má sina; encontrando apenas o riso dos ouvintes, Varejão serve de duplo para o protagonista e já prenuncia o seu desencanto.

O importante é acentuar, neste romance de estréia, a gênese de um projeto literário engajado na busca de um equilíbrio técnico que, sem eclipsar o entorno, se enraíza no sujeito para formar o seu olhar. Se em Caetés o alcance se circunscreve ao estudo de um indivíduo e do seu contexto, os romances seguintes irão aprimorar o engenho, articulando na trama uma hierarquia de entes típicos.

Vale a pena sublinhar ainda, no cerne da técnica, o juízo de Graciliano Ramos no tocante à nossa realidade: sem reacender o mito do herói civilizador, próprio da cultura indígena ${ }^{16}$, como fizeram os modernistas, nem se enganar com a miragem do progresso que contemplaria a todos, a sua visão do fracasso resiste aos apelos de evasão seja no passado seja no futuro $^{17}$. O problema brasileiro, com efeito, se desdobra entre os tempos, preservando-se, e ao escritor só a consciência fracassada no presente, invadido em sua ambigüidade, pode acusar o rastro de uma história sem reviravoltas. A chave de ouro em Iracema - "Tudo passa sobre a terra." ressoa a poética conciliadora, que ora o romancista inverte para ajustar as

16 Veja-se a tese de Egon Schaden acerca das mitologias indígenas, em que se expõe o culto à figura do herói mítico, ou herói civilizador, à qual os índios delegavam a tarefa de transformar o universo e ofertar benefícios à tribo, pois se tratava de um ente investido de poder por um ser supremo, o que sempre os desviava das ações efetivas e os levava a esperar uma intervenção mística sobre as suas adversidades. (SCHADEN, Egon. A mitologia heróica de tribos indígenas do Brasil. São Paulo: Ministério da Educação e Cultura, 1959. (Coleção Vida Brasileira)

17 Alfredo Bosi situa a visão de Graciliano Ramos nos quadros do intelectual que "morde a própria impotência e, com a mesma intensidade, acusa as razões objetivas dessa impotência, que estão na estrutura material e moral da província onde capitalismo e desequilíbrio são sinônimos perfeitos. Não cabia na consciência de Graciliano, nem no melhor romance de 1930-40, tematizar as conquistas da técnica moderna ou entoar os ritos de um Brasil selvagem. O mundo da experiência sertaneja ficava muito aquém da indústria e dos seus encantos; por outro lado, sofria de contradições cada vez mais agudas que não se podiam exprimir na mitologia tupi, pois exigiam formas de dicção mais chegadas a uma sóbria e vigilante mimese crítica." (BOSI, Alfredo. Moderno e modernista na literatura brasileira. In: Céu, Inferno. São Paulo: Ática, 1988.) 
contas com a verdade: nada passou sobre esta terra. Esse juízo se esclarece em Caetés, numa ironia cortante, mas também enforma a crítica latente dos seus outros escritos. Em crônica de 1938, Graciliano confirma seguir com a mesma idéia:

Uma parte do brasileiro quer civilizar-se, a outra conserva-se bugre, pintada a jenipapo e urucu; usa enduape e tem saudade da antropofagia. Há alguns meses, esse funcionário tamoio foi levemente funcionário e tamoio demais. Intratável, nostálgico, só pensava em Anchieta e outros missionários de épocas escuras.

Bons tempos! Não havia automóvel, nem aeroplano, essas máquinas exóticas que não se harmonizam com a índole pacífica do nosso povo, mas, em compensação, existia fé nos corações. E quando isso faltava, um medo salutar envergava os espinhaços. Bons tempos, tempos de força e de ordem!

Mas, os espíritos irrequietos inventaram novidades, cantaram a "Marselhesa", outra esquisitice, incompatível com as nossas tendências ordeiras, puseram-se a ler em demasia. Afastamo-nos da tradição.

Necessário pôr fim a semelhantes desregramentos, retornar o bom caminho. Pois não! Seria bom a gente recuar uns duzentos anos, suprimir inovações perigosas e adotar a candeia de azeite.

Dois séculos ou mais.

Devíamos era restaurar o Brasil de Cunhambebe, rebaixar o funcionário e elevar o canibal.

Parece que o cartão postal, que vi na escola primária, estava certo. Dois tipos: - um vestido, carregado de papel impresso; outro nu, feroz, com os dentes pontudos, cacete na mão. ${ }^{18}$ 


\section{Datas de recebimento e aprovação dos artigos desta edição}

Cinema = Cavação:

Cendroswald Produções Cinematográficas

Carlos Augusto Calil

Recebido em 8 de junho de 2008

Aprovado em 6 de agosto de 2008

O lobisomem entre índios e brancos:

o trabalho da imaginação no Grão-Pará no final do século XVIII

Mark Harris

Recebido em 28 de abril de 2008

Aprovado em 29 de junho de 2008

A teoria da história de Caio Prado Jr.:

dialética e sentido

Jorge Grespan

Recebido em 1 de abril de 2008

Aprovado em 2 de maio de 2008

Caio Prado Jr. e a história agrária do Brasil e do México

Guillermo Palacios

Recebido em 27 de março de 2008

Aprovado em 12 de maio de 2008

Fronteiras da desordem:

saber e ofício nas experiências de Hélio Oiticica no Morro da Mangueira e de Carlos Nelson Ferreira dos Santos em Brás de Pina

Magaly Marques Pulhez

Recebido em 17 de abril de 2008

Aprovado em 24 de junho de 2008

"O linguajar multifário":

os estrangeiros e suas línguas na ficção de Mário de Andrade

Maria Caterina Pincherle

Recebido em 20 de março de 2007

Aprovado em 6 de agosto de 2008

Os nomes da língua:

configuração e desdobramentos do debate sobre a língua brasileira no século XIX

Olga Ferreira Coelho

Recebido em 26 de maio de 2007

Aprovado em 6 de agosto de 2008

Caetés:

nossa gente é sem herói

Erwin Torralbo Gimenez

Recebido em 5 de janeiro de 2007

Aprovado em 6 de agosto de 2008 